Hanawalt, V. M. \& Sampson, J. (1947). Am. J. vet. Res. 8, 235.

McCance, R. A. \& Widdowson, E. M. (19.59). Y. Physiol., Lond. 147, 124.

Morrill, C. C. (1952a). Am. \%. vet. Res. 13, 164.

Morrill, C. C. (1952b). Am. J, vet. Res. 13, I71.

Morrill, C. C. (1952c). Am. Y. vet. Res. 13, 322.

Morrill, C. C. (1952d). Am. \%. vet. Res. I3, 325 .

Mount, L. E. (1959). F. Physial., Lond. 147, 333.

Mount, L. E. (196x). Ciba Fdn Symp.: Somatic Stability in the Newly Bom, p. I 7 . [G. E. W. Wolstenholme and M. O'Connor, editors.] London: Churchill.

Mount, L. E. (1964). F. Physiol., Lond. 170, 286.

Mount, L. E. (1968). The Climatic Physiology of the Pig. London: Edward Arnold.

Newland, H. W., McMillen, W. N. \& Rcincke, E. P. (1952). F. Anim. Sci. rr, I 8.

Pomeroy, R. W. (1953). F. agric. Sci, Camb. 43, 182.

Widdowson, E. M. (1950). Nature, Lond. I66, 626 .

\title{
Nutrition and temperature control in the newborn baby
}

\author{
By David Hull, Institute of Child Health, University of London, 30 Guilford Street, \\ London, WCr
}

At birth the constant supply of oxygen and food which the developing foetus enjoys in the uterus suddenly stops. The newborn infant quickly cstablishes an alternative source of oxygen when he expands his lungs and begins to breathe, but an alternative supply of nutrients is not obtained so quickly. Even if he is allowed to suckle at birth there is inevitably some delay before intestinal absorption of milk is sufficient to meet his metabolic needs. Thus he mobilizes his own food reserves and this leads to a change which is as fundamental, although not as dramatic, as the commencement of breathing, for in the uterus, glucose is probably the main source of cellular energy whereas after birth fatty acids play the major part.

After birth the resting rate of oxygen consumption increases over the first few hours or days of life. This is not surprising because the ncwborn infant moves his limbs more than the foetus and begins to breathe, suckle, digest and excrete for himself. Furthermore, he must vary his metabolic rate to maintain a constant internal thermal environment. This puts added demands on his limited food stores. Recent investigations have shown that the human infant like many newborn mammals has a supply of fat tucked away for the sole purpose of heat production in a special tissue called brown adipose tissue. Brown adipose tissue is a fat-storing tissue and therefore it must also be considered as a possible source of circulating free fatty acids. Indeed Shattock (I 909), noting its rich blood supply, suggested that the special function of brown adipose tissue was the rapid supply of fat in an emergency.

Circulating free fatty acid ( $F F A$ ) levels in newborn infants

A rise in plasma FFA from a cord level below $0.4 \mathrm{~m}$-equiv./1. to values ranging between 0.8 and $\mathrm{I} .2 \mathrm{~m}$-equiv. 1 . within $24 \mathrm{~h}$ of birth have been observed in fullterm human infants (Van Duyne \& Havel, r959; Novak, Hahn, Koldovsky \& 
Melichar, 1964; Persson \& Gentz, I966; Keele \& Kay, 1966). Similar rises in plasma FFA have been reported in newborn sheep (Van Duyne, Parker, Havel \& Holm, 1960) and rats (Novak, Hahn, Koldovsky \& Mclichar, 1965). 'This rise in FFA has been attributed to the mobilization of depot fat in response to the interruption of the placental supply of nutrients.

Where do the fatty acids come from? Fat is stored in the liver and adipose tissue and it is interesting and possibly relevant to consider the development of these fatstoring organs. In lower vertebrates, e.g. fish and reptiles, the liver can be the principle organ of storage and it may have an important temporary role in the foetus during development. Adipose tissue, as it is found in man, is peculiar to homoeothermic animals, i.e. birds and mammals. It is one of the last specific tissues to develop and it is found in two distinct forms, brown and white. The first to appear is brown adipose tissue. This is characteristically found around the neck extending backwards between the scapulac and laterally under the clavicles to the axillac; it also spreads downwards into the thorax around the oesophagus, trachea and major vessels (Dawkins \& Hull, I965). It may also be found on the posterior abdominal wall, around the kidneys and in the groin. White adipose tissue appears later and its cell origin is still a subject of controversy. Some claim that white adipose tissue may arise at any time from fibroblasts, whereas others state that it is always a distinct cell line (Wasserman, r965). The morphological distinction between brown and white adipose tissue was made many years ago (Hammar, I895). The amount of fat stored in these tissues at birth varies considerably from species to species. The rat and pig have only I I $\mathrm{g}$ fat/kg body-weight at birth (Widdowson, I950). In the rat very little fat can be seen histologically in brown or white adipose tissue though both tissues are present at birth. The lamb has $30 \mathrm{~g}$ fat $/ \mathrm{kg}$ body-weight (Alexander, I 962) and histologically both white adipose tissue in lobes between the muscles of the trunk and brown adipose tissue from within the thorax contain moderate amounts of fat. The newborn rabbit has $54 \mathrm{~g}$ fat $/ \mathrm{kg}$ body-wcight, approximately half of which is in brown adipose tissue (Hull, Shelley $\&$ Young, unpublished). The fat content of the human foetus is $16 \mathrm{I} \mathrm{g}$ fat $/ \mathrm{kg}$ body-weight at term (Widdowson \& Spray, 195I). Thus the mature human infant has a comparatively large fat store at birth; both brown and white adipose tissue are well filled but it is difficult to determine exactly how much is in each because at certain sites, e.g. the axillae and perirenal deposits, the two cell types are intermingled (Aherne \& Hull, 1966). Crude dissection indicates that there may be between 20 and $30 \mathrm{~g}$ of brown adipose tissue in a full-term infant which would contain about $10-15 \mathrm{~g}$ of fat, that is under $3 \%$ of the body fat at birth.

Unlike the human infant, the newborn rat, rabbit and lamb suckle and receive a good milk feed at the time of birth. Rat colostrum contains $22 \%$ fat (Luckey, Mende \& Pleasants, I954). Comparisons between animal experimental situations and changes seen in babies must be made with these differences in mind.

If the rise in plasma FFA seen after birth indicates fatty acid mobilization in response to an interruption in the placental supply of glucose then one might expect that it would occur in the newborn rabbit as it does in the rat, sheep and man. 
Indeed it does if the rabbit is delivered normally and left in the nest, but it does not if it is delivered by Caesarean section and kept in a thermal neutral environment (Hardman \& Hull, to be published). Even after $24 \mathrm{~h}$ starvation the plasma FFA level of the naturally delivered rabbit was still raised so it seems unlikely that it was due to the milk feed alone. On the other hand, the naturally delivered rabbit would experience a certain amount of cold exposure. If rabbits born by Caesarean section are deliberately exposed to cold for $\mathrm{I} h$ their plasma FFA increases from approximately $0.4 \mathrm{~m}$-equiv. $/ 1$. to $0.7 \mathrm{~m}$-equiv. $/ 1$. If the environmental temperature was reduced further until their colonic temperature fell then the level of plasma FFA rose even higher. This suggests that two mechanisms are involved: firstly with mild cold exposure the rise in plasma FFA is due to an increase in FFA mobilization possibly in response to the increased metabolic rate, and secondly with hypothermia a further rise in FFA level occurs due to a reduction in FFA utilization.

There is some evidence that under some conditions both mechanisms may operate in man. When fat is hydrolysed it breaks down to free fatty acid and glycerol. Glycerol cannot be used by the adipose cell because it lacks the enzyme glycerol-kynase and therefore it spills into the circulation to be metabolized in the liver or elsewhere. In vitro, brown adipose tissue, when hydrolysis is stimulated by addition of noradrenaline, releases comparatively large amounts of glycerol into the medium whereas much of the fatty acid released is oxidized or resynthesized within the cells. On exposure to cold the serum glycerol level of newborn rabbits rises from a resting level just below $0.1 \mathrm{~m}$-mole/1. to a little above $0.5 \mathrm{~m}$-mole $/ 1$, and there is a good correlation in the steady state between the increase in metabolic rate and the rise in serum glycerol. This suggests that the glycerol level in newborn rabbits indicates the metabolic activity in brown adipose tissue (Hardman \& Hull, to be published). Dawkins \& Scopes (1965) observed a rise in the serum glycerol of newborn infants $6-3 \circ \mathrm{h}$ old who were exposed to a cool environment $\left(25^{-2} 6^{\circ}\right)$ for $20 \mathrm{~min}$, but there was no significant change in plasma FFA, which remained at the low level of 0.34 m-equiv. 1 . Melichar \& Wolf (1967) measured serial FFA and glycerol levels in full-term and premature infants. The premature infants they divided into two groups, those who maintained a good colonic temperature and those who did not. A rise in FFA and glycerol occurred in all three groups over the first $24 \mathrm{~h}$ of life. The rise in FFA was a little lower in the premature infants at $3 \mathrm{~h}$, but at $24 \mathrm{~h}$ the mean level in the cold premature infants was $\mathrm{I} 5 \mathrm{~m}$.equiv./1., compared to 0.9 m-equiv. $/ 1$. in the warmer premature and mature infants. A rise in serum glycerol occurred in all three groups, small in the mature infants, and largest in the cold premature infants. It is possible therefore that some of the rise in FFA in all groups was due to cold exposure, and that the higher level in the cold premature infants was due to hypothermia. It would be interesting to know whether FFA and glycerol levels change if care is taken to avoid the cold exposure which immediately follows birth. It would, of course, be wrong to assume that a rise in plasma FFA necessarily means an increase in turnover or that an increase in turnover would necessarily be accompanied by a rise in plasma level.

From the clinical point of view there is some evidence to suggest that in sick 
infants it is not the mobilization of fat which presents the problem but its utilization in the tissues. Aherne (1965) reported that many babies who died when 2-3 days old had excessive fat deposits in many organs, in particular the diaphragm, heart muscle and liver. It was more marked in undernourished infants.

\section{Temperature control}

It has often been said that newborn mammals have poor thermal control, and this is true if they are challenged by the range of environmental conditions normally weathered by adults. But this is not because they have poor thermoregulatory mechanisms, as was once supposed, but because of the severe limitations placed on their thermal responses by their small size and poor thermal insulation. Thus the lowest comfortable or critical temperature for a naked mature infant is about $34^{\circ}$ and for the premature infant it is even higher. This ambient temperature would be intolerably hot for an adult. When the temperature drops below $34^{\circ}$ extra heat is produced by the infant to maintain thermal stability and the rate of oxygen consumption rises from about $6 \mathrm{ml} / \mathrm{kg}$ min to a maximum about $14 \mathrm{ml} / \mathrm{kg}$ min (Brück, I961; Scopes, I966; Adamsons, 1966). This maximum is reached when the ambient temperature is about $25^{\circ}$, which is just below the thermal neutral range for naked man. Fully clothed we still find this temperature uncomfortably warm. Most infants nursed naked in incubators at temperatures commonly used in clinical practice experience some degree of cold exposure. E. N. Hey \& B. O'Connell (personal communication) have shown that even swaddled infants covered with a blanket increase their metabolic rate if the room temperature falls below $25^{\circ}$. The infants are most at risk immediately after birth when cold air blows on their wet exposed skin. Many infants leave the labour room with low body temperatures. The old practice of putting babies in bed with mother immediately after delivery, which is now felt valuable for the future emotional welfare of mother and child, may well have more obvious and simple benefits.

Babies do not show they are cold because, unlike adults and newborn pigs, they do not shiver. The site of this non-shivering heat production is probably brown adipose tissue. The evidence is as follows:

In the newborn rabbit (Dawkins \& Hull, ı 964), guinea-pig (Brück \& Wünnenberg, I965a,b,c), rat (Cockburn, Hull \& Walton, I967) and coypu (Hull, unpublished) thermocouples on brown adipose tissue have shown that heat is produced in the tissue when the animal is exposed to cold. It is difficult to make similar observations in the human infant because of the insulating capacity of the skin and underlying layer of fat; nevertheless Silverman, Zamelis, Sinclair \& Agate (1964) showed that the skin over the nape of the neck stayed relatively warmer then elsewhere when infants were in a cool environment. The newborn rabbit weighs about $60 \mathrm{~g}$ and has about $2.5 \mathrm{~g}$ of brown adipose tissue. On cold exposure the rabbits' rate of oxygen consumption rises from $25 \mathrm{ml} / \mathrm{kg} \min (1 \cdot 5 \mathrm{ml} / \mathrm{min})$ to 65 $\mathrm{ml} / \mathrm{kg} \mathrm{min}(3.9 \mathrm{ml} / \mathrm{min})$. Brown adipose tissue is the main site of heat production in newborn rabbits (Hull \& Segall, I965a; Heim \& Hull, I966) and thus its brown adipose tissue when maximally stimulated must consume oxygen at a rate of about 
I $\mathrm{ml} / \mathrm{g}$ tissue min. In the human infant the maximum rate of oxygen consumption is $I_{4} \mathrm{ml} / \mathrm{kg} \mathrm{min}$ and the resting level approximatcly $6 \mathrm{ml} / \mathrm{kg} \mathrm{min}$. If brown adipose tissue in infants consumes oxygen and thus produces heat at the same rate as brown adipose tissue in rabbits, an infant weighing $3.5 \mathrm{~kg}$ would need $3^{\circ} \mathrm{g}$ brown adipose tissue to support the above increase in heat production. Crude estimates suggest that amounts close to this may well be present. The hypothesis that brown adipose tissue is an important site of heat production in newborn infants is supported by two further pieces of evidence. Firstly Karlberg, Moore \& Oliver (1962) showed that intravenous infusion of noradrenaline into human infants caused a rapid rise in oxygen consumption and colonic temperature. Noradrenaline is a powerful stimulant of thermogenesis in brown adipose tissue both in vivo and in vitro (Dawkins \& Hull, 1964). Secondly, experimental evidence has shown that with cold exposure the fat content of brown adipose tissue slowly falls (Hull $\&$ Segall, $1965 b$ ). The brown adipose tissue of infants who died with the cold syndrome was largely depleted of fat (Aherne \& Iull, I 966). The tissue produces heat by the intracellular oxidation of fatty acids. The fact that it can be depleted of fat whilst white adipose tissue remains well filled suggests that the tissue can burn fat faster than it can be replaced.

In conclusion the helpless sleepy newborn infant achieves remarkable metabolic changes in the first few days of life. The rapidly growing tissues of his body continue to have an adequate supply of oxygen and energy-rich nutrients and to be nurtured at a suitable temperature. We are only beginning to learn the secrets of his success.

\section{REFERENCES}

Adamsons, K. (1966). Pediat. Clins N. Am. 13, 599.

Aherne, W. (1965). Archs Dis. Childh. 40, 406.

Aherne, W. \& Hull, D. (1 966). F. Path. Bact. 9r, 223.

Alexander, G. (1962). Aust. F. agric. Res. 13, 144.

Brück, K. ( I96r). Biol. Neonat. 3,65.

Brück, K. V. \& Wünnenberg, B. (1965a). Pfiügers Arch. ges. Physiol. 282, 362.

Brück, K. \& Wünnenberg, B. (1965b). Pfiugers Arch. ges. Physiol. 282, 376.

Brück, K. \& Wünnenberg, B. (I965c). Pfligers Arch. ges. Physiol. 28, 1 .

Cockburn, F., Hull, D. \& Walton, I. (1967). Br. F. Pham. Chemother. 3x, 568.

Dawkins, M. J. R. \& Hull, D. (I964). F. Physiol., Lond. 172, 2 I6.

Dawkins, M. J. R. \& Hull, D. (1965). Scient. Am, 213, 62.

Dawkins, M. J. R. \& Scopes, J. W. (1965). Nature, Lond. 206, 201.

Hammar, J. A. (1895). Arch. Mikr. Anat. 45, 5 I2.

Heim, T. \& Hull, D. (1966). F. Physiol., Lond. 186, 42.

Hull, D. \& Segall, M. M. (1965a). \%. Physiol, Lond. 181, 449.

Hull, D. \& Segall, M. M. $(1965 b)$. F. Physiol., Lond. 18I, 468.

Karlberg, P., Moore, R. E. \& Oliver, T. K. (r962). Acta puediat., Stokh. 51, 284 .

Keele, D. K. \& Kay, J. L. (1966). Pediatrics, Springfield 37, 597.

Luckey, 'T. D., Mende, 'T. J. \& Pleasants, J. (I954). J. Nutr. 54, 345.

Melichar, V. \& Wolf, II. (1967). Biol. Neonat. Ix, 50.

Novak, M., Hahn, P., Koldovsky, O. \& Melichar, V. (1964). Biol. Neonat. 7, 179.

Novak, M., Hahn, P., Koldovsky, O. \& Melichar, V. (1965). Physiol. bohemoslov. 14, 38.

Persson, B. \& Gentz, J. (1966). Acta paediat, Siockh. 55, 535.

Scopes, J. W. (1966). Br. med. Bull. 22, 88.

Shattock, S. G. (1909). Proc. R. Soc. Med. Path. Sect. 2, 252.

Silverman, W. A., Zamelis, A., Sinclair, J. C. \& Agate, F. J. Jr (r964). Pediatrics, Springfield $33,984$. 
Van Duyne, C. M. \& Havel, R. J. (1959). Proc. Soc. exp. Biol. Med. roz, 599.

Van Duyne, C. M., Parker, H. R., Havel, R. J. \& Holm, L. W. (r960). Am. J. Physiol. r99, 987.

Wasserman, F. (1965). In Handbook of Physiology. Section 5. Adipose Tissue. [A. E. Renold and G. F. Cahill, editors.] Washington DC: American Physiological Society.

Widdowson, E. M. (1950). Nature, Lond. 166, 626.

Widdowson, E. M. \& Spray, C. M. (r95I). Archs Dis. Childh. 26, 205.

\section{The starving newborn baby}

\section{By A. W. Wilkinson, Institute of Child Health, Hospital for Sick Children, London, $W C \mathrm{I}$}

In the newborn baby starvation implies the failure to consume and absorb enough calories and other materials to satisfy fully the requirements for growth as well as maintenance. If surgical treatment is necessary, involving the infliction of injury, these basic requirements are increased in order to provide for the resulting larger energy consumption and for the inflammatory response. Although the starving subject heals satisfactorily at any age, especially when the pre-operative nutritional state is good, this is achieved at the expense of the endogenous provision of the necessary materials. Such healing occurs normally and uneventfully in babies born as much as 8 weeks prematurely, who may weigh less than $2 \mathrm{~kg}$, or who have been starved almost completely for up to ro days or more, and may have lost a quarter of their stated birth weight.

Pure starvation is seldom seen in surgical patients because they usually have some form of intestinal obstruction, which by vomiting causes the loss of upper gastrointestinal secretions. It must also be emphasized that there is almost always some uncertainty about the stated birth weight, about the quantity and composition of the material which has been vomited, the amount of milk which has been consumed and how much of it has been retained.

Some degree of starvation occurs even in normal newly born babies in the widely varying period of time between the ligation of the umbilical cord and the starting of milk feeds. This delay occurs even when an abundant supply of expressed human breast milk is regularly offered to the baby from a few hours after birth, and appears to be due to the failure of the baby to consume milk rather than to the deficient production of milk by the mother (Wilkinson, Stevens \& Hughes, 1962). This delay is increased by foetal distress and after difficult or prolonged labour. During this sort of starvation immediately after birth the output of nitrogen, potassium and sodium in the urine is small, partly because so little urine is formed, perhaps only to $\mathrm{ml}$ per $\mathrm{kg}$ per $24 \mathrm{~h}$. When the volume of urine rises after the intake of milk begins there is usually an increase in the output of nitrogen for a few days although the output of potassium and sodium fall. Starvation of this kind immediately after birth is accompanied by a loss of weight which varies a good deal and is related more closely to the birth weight of the baby than to factors such as foetal distress (Fig. I). 